\title{
Change in Central Corneal Thickness after Phacoemulsification
}

\author{
Fariha S. Wali ${ }^{1}$, Sajjad Ali Surhio ${ }^{2}$, Rafeen Talpur ${ }^{3}$, Muhammad Jawed ${ }^{4}$, Shehnilla Shujaat ${ }^{5}$ \\ ${ }^{1-5}$ Department of Ophthalmology, Sindh Institute of Ophthalmology and Visual Sciences, Hyderabad - Pakistan
}

\begin{abstract}
Purpose: To determine changes in central corneal thickness after phacoemulsification at first post-operative day, one week and one month.

Study Design: Descriptive Observational study.

Place and Duration of Study: Sindh Institute of Ophthalmology and Visual Sciences, Hyderabad. From June 2018 to March 2019.

Material and Methods: Ninety-two patients with ages between 35 and 72 years presenting with senile and presenile cataract were selected by non-probability convenience sampling. Patients with previous ocular surgery, ocular trauma, Glaucoma, Uveitis, Contact lens wear and long-term use of ocular medication were excluded. The patients were subdivided into three groups depending on variability in their corneal thickness. Patients with preoperative central corneal thickness (CCT) from 480 to $529 \mu \mathrm{m}$ were placed in group 1 (Thin), group 2 included patients with CCT ranging between 530 and $569 \mu \mathrm{m}$ (Moderate), patients with CCT from 570-640 $\mu \mathrm{m}$ were placed in group 3 (Thick). Preoperative CCT was measured before extraction of cataract with phacoemulsification and then repeated on first post-operative day and then at one week and one month.

Results: Preoperative mean central corneal thickness increased by $10.2 \%$ on first post-operative day. It reduced to $3.1 \%$ on seventh post-operative day. It further reduced to $0.7 \%$ on $30^{\text {th }}$ post-operative day. Central corneal thickness reduced to mean value of $548.8 \mu \mathrm{m}$ on $30^{\text {th }}$ post-operative day, which was statistically non-significant as compared with preoperative mean value $(544.96 \mu \mathrm{m})$.
\end{abstract}

Conclusion: There was no statistically significant change in CCT one month after phacoemulsification when compared with the pre-operative CCT.

Key Words: Pachymetry, Central Corneal Thickness, Phacoemulsification, Cataract.

How to Cite this Article: Wali FS, Surhio SA, Talpur R, Jawed M, Shujaat S. Change in Central Corneal Thickness after Phacoemulsification. Pak J Ophthalmol. 2020; 36 (1): 67-71.

DOI: https://doi.org/10.36351/pjo.v36i1.999.

\section{INTRODUCTION}

Corneal endothelium consists of a monolayer of polygonal cells. Endothelial cells maintain this tissue in a dehydrated state by their pumping activity, thereby assuring its transparency ${ }^{1}$. This is an active

Correspondence to: Muhammad Jawed

Sindh Institute of Ophthalmology and Visual Sciences, Hyderabad-Pakistan

Email: jawedbiotech@yahoo.com process, which is controlled by $\mathrm{Na}^{+} / \mathrm{K}^{+}$-ATPase ${ }^{2}$. Numerical density of $400-500$ cells $/ \mathrm{mm}^{2}$ is required to sustain the pumping activity of the endothelium. Dysfunction of endothelial cells results in water accumulation in the cornea causing increased thickness of cornea ${ }^{3}$.

Thickness of the cornea is an important parameter to see the endothelial cell function ${ }^{4}$. Positive correlation exists between endothelial cell function and Central corneal thickness (CCT) ${ }^{5}$. Central corneal thickness can be measured by ultrasonic pachymeter ${ }^{6}$. 
Ultrasonic pachymeters allow surgeons to measure the thickness of the cornea in patients suffering from glaucoma, hypertension or those who are considered for refractive surgery without causing damage to this sensitive organ. Measurements of CCT are useful to evaluate corneal hydration and the corneal endothelial cells function ${ }^{7}$. When functioning normally, the endothelial pump balances the leak rate to maintain the corneal stromal water content at $78 \%$ and the CCT at $\sim 540 \mu \mathrm{m}$ that is considered as the normal $\mathrm{CCT}^{8}$.

Phacoemulsification is one of the most widely used surgical procedures for removal of cataract ${ }^{9,10}$. The corneal endothelium is known to undergo damage during phacoemulsification due to incision, use of ultrasonic energy, irrigation solutions, visco-elastics, $\operatorname{etc}^{11}$. Precise measurements of corneal thickness may therefore serve as a parameter for assessing overall endothelial function. A healthy cornea is able to compensate rapidly for transient increases in CCT after cataract surgery ${ }^{12,13}$.

In the following study, we present our results of measurement of CCT before and after phacoemulsification to evaluate the recovery of endothelial cell function at one month after surgery.

\section{MATERIAL AND METHODS}

In this observational study, participants were recruited from outpatient department of Sindh institute of Ophthalmology and Visual Sciences, Pakistan. Consent was taken from participants. All the participants were divided into 3 sub-groups based upon normal variability in their corneal thickness. Group 1 included patient who had preoperative corneal thickness from 480 to $529 \mu \mathrm{m}$, Group 2 covered patients whose preoperative corneal thickness ranged from 530 to $569 \mu \mathrm{m}$. Group 3 patients had corneal thickness ranging from 570 to $640 \mu \mathrm{m}$. This division into sub groups decreased the chances of error when comparing thin corneal behavior with thick corneas ${ }^{14}$.

All patients aged between 35 and 72 years, presenting with pre-senile and senile cataract were included and all the patients with diabetes, previous ocular surgery, ocular trauma, Glaucoma, Uveitis, Contact lens wear and long-term use of ocular medication were excluded from the study.

After acquiring CCT by means of ultrasonic pachymeter (Pacline Optikon, Italy), patients were scheduled for phacoemulsification with intra ocular lens implant. Experienced surgeons operated all patients. On first postoperative day, patients were prescribed topical antibiotics and steroids. Any patient with striate keratopathy was excluded from the study. All the patients were examined on $7^{\text {th }}$ day and after one month of surgery and CCT were measured.

\section{RESULTS}

In this study, 92 participants were included, the Male: Female ratio was 5:4. Age of patients ranged from 35 to 72 years (mean age 53.3 years \pm 12.0 ). Fig. 1 shows the mean CCT of first sub-group with CCT ranged between 450 and $529 \mu \mathrm{m}$, which increased to a level of $558.4 \mu \mathrm{m}$ from baseline of $497.65 \mu \mathrm{m}$ on first postoperative day, which then reduced to $526.75 \mu \mathrm{m}$ on seventh post-operative day. On $30^{\text {th }}$ day, the mean CCT reduced to $502 \mu \mathrm{m}$.

Second sub-group had a CCT ranging from 530 to

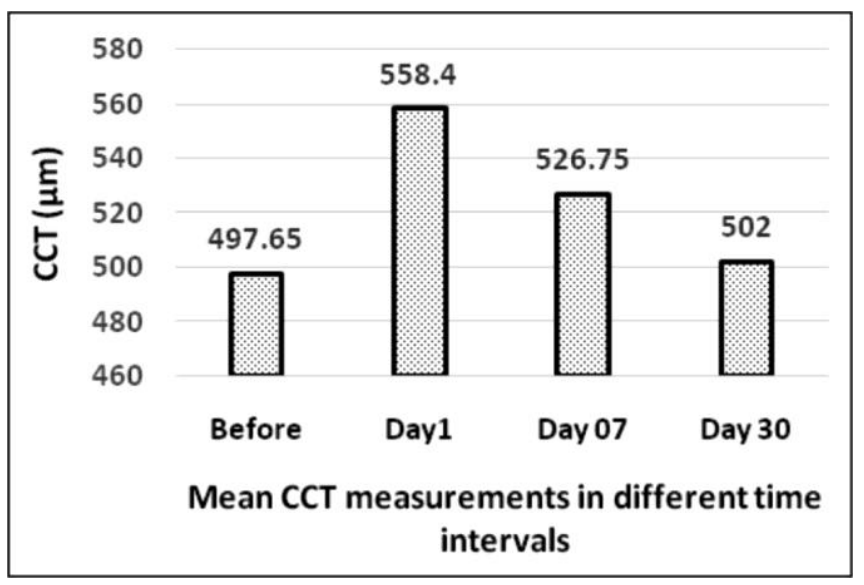

Fig. 1: Correlation of CCT in Sub-Group1 (Thin CCT; 450 $529 \mu \mathrm{m})$, before and after Phacoemulsification.

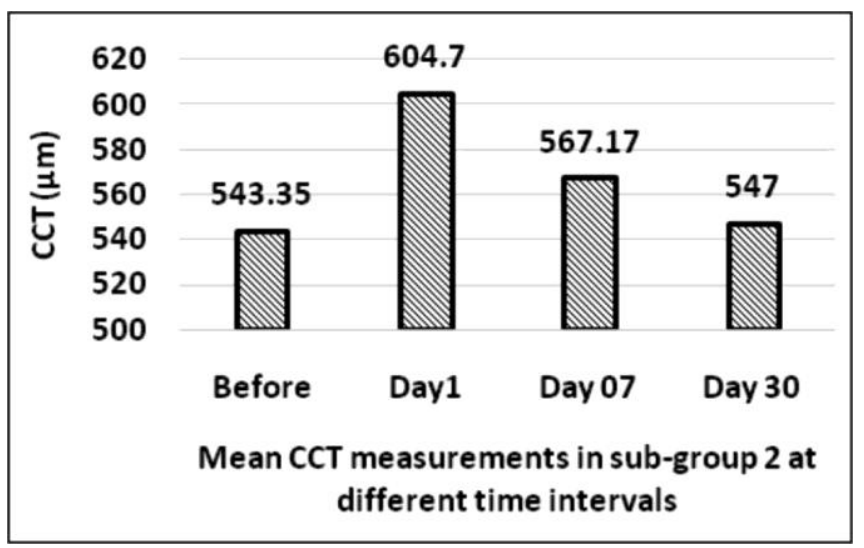

Fig. 2: Correlation of CCT in Sub-Group 2 (Normal CCT; 530 $569 \mu \mathrm{m})$, before and after Phacoemulsification. 
$569 \mu \mathrm{m}$, as shown in Fig. 2 the mean CCT increased to a level of $604.7 \mu \mathrm{m}$ from baseline of $543.35 \mu \mathrm{m}$ on first post-operative day, reduced to $567.17 \mu \mathrm{m}$ on seventh post-operative day and on $30^{\text {th }}$ day, the mean CCT of second sub-group reduced to $547 \mu \mathrm{m}$.

In $3^{\text {rd }}$ subgroup CCT ranged from $570-650 \mu \mathrm{m}$, there was increase in average CCT of $635.16 \mu \mathrm{m}$ from baseline mean of $593.9 \mu \mathrm{m}$ on first post-operative day. It reduced to mean of $603.5 \mu \mathrm{m}$ on $7^{\text {th }}$ day and then to $597.5 \mu \mathrm{m}$ at one month (Fig. 3).

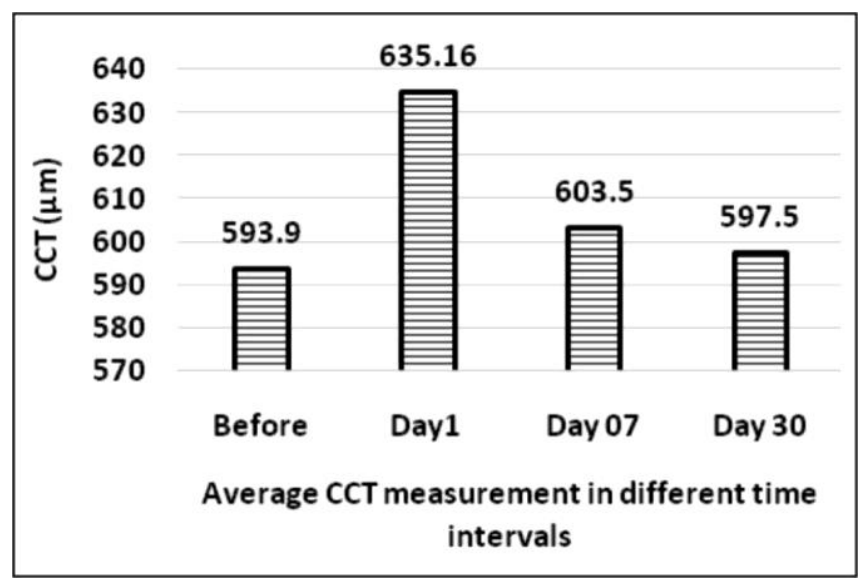

Fig. 3: Correlation of CCT in Group-3 (Thick CCT; $570-640 \mu \mathrm{m}$ ), before and after Phacoemulsification

In all sub groups, there was a mean increase in CCT to $599.42 \mu \mathrm{m}(10.2 \%$ increase $)$ on $1^{\text {st }}$ day postoperatively, $565.8 \mu \mathrm{m}(3.1 \%)$ on $7^{\text {th }}$ day, and $548.3 \mu \mathrm{m}$ $(0.7 \%)$ on $30^{\text {th }}$ day.

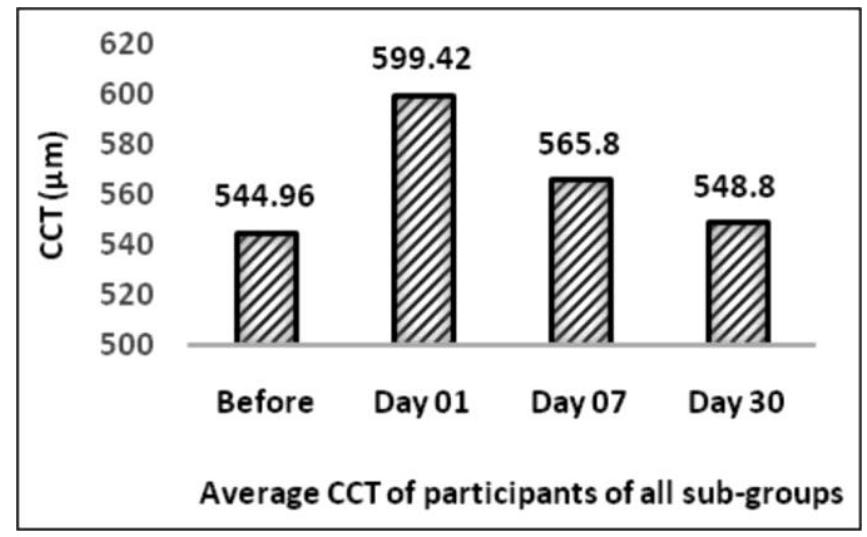

Fig. 4: Mean CCT of all participants at different time intervals.

\section{DISCUSSION}

Corneal endothelium maintains deturgescence by pumping fluid out of the corneal stroma. After phacoemulsification, endothelial cell function may alter due to inflammation or surgical trauma. This leads to increase in corneal thickness, which can be measured by Pachymetry. Repeated Pachymetry over a period after phacoemulsification can give us indirect information about endothelium cell function.

Corneal endothelium is exposed to different insults during cataract surgery, which even if mild can cause transient alterations in endothelial cell function. This leads to increase in CCT. Surgical instruments, viscoelastics, and solutions used for irrigation and aspiration can induce changes in endothelium by direct trauma or by inflammatory process ${ }^{15,16}$. Decreased pumping action of endothelium to maintain corneal deturgesence leads to increased corneal thickness ${ }^{4,17}$. This change can easily be quantified by the use of pachymeter to measure corneal thickness ${ }^{18}$. Corneal endothelium slowly recovers from the insult and pumps the fluid out of the cornea. Over a time-period, the cornea regains its normal thickness. The duration of recovery may vary from patient to patient depending on general health, corneal endothelial cell count, surgical trauma and inflammatory response ${ }^{19,20}$. In our study, CCT was measured over a period of one month postoperatively to allow enough time for recovery. Results in all the groups showed that preoperatively healthy corneas were able to recover smoothly to approximately the same thickness as it was preoperatively.

Changes in the endothelial function depicted by Pachymetry to measure CCT is also discussed by OT Aribaba et $\mathrm{al}^{21}$. They showed an increase in mean CCT

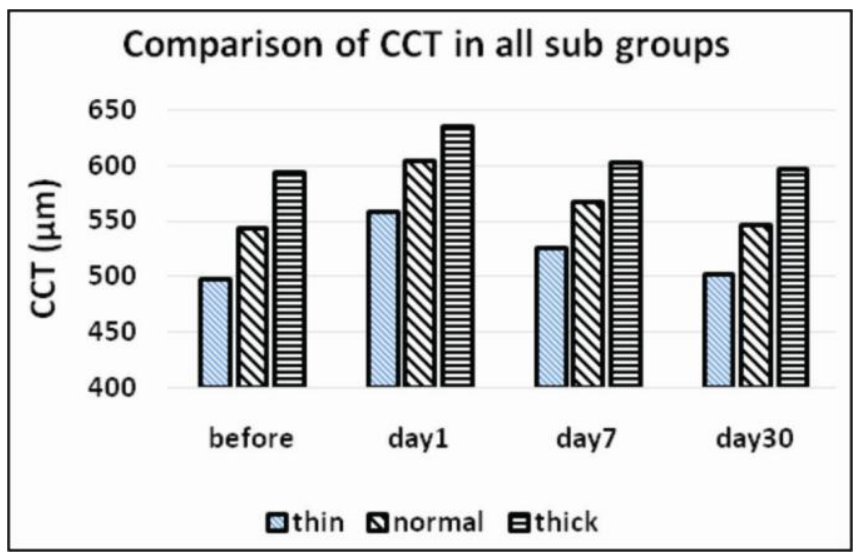

Fig. 5: Comparison of Central Corneal thickness (CCT) in 3 subgroups before and after Corneal Surgery.

CCT; Central Corneal Thickness, Thin; sub-group with CCT $450-529 \mu \mathrm{m}$, Normal; sub-group with CCT $530-569 \mu \mathrm{m}$, Thick; sub-group with CCT $570-640 \mu \mathrm{m}$. 
from $520.6 \pm 20.3 \mu \mathrm{m}$ to $597.9 \pm 30.4 \mu \mathrm{m}, 24$ hours after cataract surgery followed by relative reduction in the mean CCT to $555.2 \pm 24.7 \mu \mathrm{m}$ and $525.1 \pm$ $19.7 \mu \mathrm{m}$ at 2 weeks and 12 weeks, respectively.

Another study showed that there was no statistically significant difference in CCT after small incision cataract surgery and phacoemulsification ${ }^{22}$. Similarly, Ganekal S, Nagarajappa A. have shown results consistent with our study ${ }^{23}$.

In the immediate post-operative period in cataract surgery, central corneal thickness increases but this change is reversible. These changes come to base line after some time. However, the transient increase in central corneal thickness may give falsely high intra ocular pressures. Hence, if spikes in intra ocular pressure are noticed in the early post-operative period, it should not be treated until central corneal thickness is also taken into account.

Limitations to our study are shorter study time, and lack of information about endothelial cell count measured by specular microscopy. On the other hand, in this study we used ultrasound Pachymetry, which is shown to have more variable results as compared to optical Pachymetry.

\section{CONCLUSION}

Corneal thickness increases transiently after phacoemulsification due to surgical trauma and inflammation. Corneal endothelium recovers its normal function and corneal thickness reduces to preoperative level over one month.

\section{Ethical Approval}

The study was approved by the Institutional review board/Ethical review board.

\section{Conflict of Interest}

Authors declared no conflict of interest

\section{Authors' Designation and Contribution}

Fariha Sher Wali; Assistant Professor: Study design, data collection, manuscript drafting, and final review.

Sajjad Ali Surhio; Associate Professor: Data collection, manuscript drafting, final review.

Rafeen Talpur; Assistant Professor: Data collection, final review.
Muhammad Jawed; Research Associate: Data collection, manuscript drafting, final review.

Shehnila Shujaat; Assistant Professor: Data collection, final review.

\section{REFERENCES}

1. Ali M, Raghunathan V, Li JY, Murphy C, Thomasy S. Biomechanical relationships between the corneal endothelium and Descemet's membrane. Exp Eye Res.2016; 152: 57-70.

Doi:10.1016/j.exer.2016.09.004.

2. Thériault M., Roy O, Brunette I, Proulx S. Physiological pressure enhances the formation of tight junctions in engineered and native corneal endothelium. Exp Eye Res. 2019; 179: 102-105.

Doi:10.1016/j.exer.2018.11.004

3. Whikehart DR. Corneal Endothelium: Overview, in Encyclopedia of the Eye, D.A. Dartt, Editor. Academic Press: Oxford, 2010: 424-434.

4. Maugeri G, Longo A, D'Amico, Agata G, Rasà D, Maria, Reibaldi M, Russo A, et al. Trophic effect of PACAP on human corneal endothelium. Peptides, 2018; 99 (1): 20-26.

5. Doughty MJ, Jonuscheit S. Corneal structure, transparency, thickness and optical density (densitometry), especially as relevant to contact lens wear-a review. Cont Lens Anterior Eye, 2019; 42 (3): 238-245.

6. Hoehn AL, Thomasy SM, Kass PH, Horikawa T, Samuel MS, Shull OR, et al. Comparison of ultrasonic pachymetry and Fourier-domain optical coherence tomography for measurement of corneal thickness in dogs with and without corneal disease. The Vet J. 2018; 242: 59-66.

7. García JE, Camarena C, Ramírez F, Zavala D, Lloves, J. Correlation of age, corneal curvature and spherical equivalent with central corneal thickness. Revista Mexicana de Oftalmología, 2017; 91 (4): 172176.

8. Marelli A, DeVita I, Cozza F, Tavazzi S. Criticality of the measurement of corneal thickness in specular reflection by digital biomicroscope. Cont Lens Anterior Eye, 2018; 41 (6): 531-537.

9. Rouhbakhshzaeri M, Azar N, Ghahari E, Putra I, Eslani M. New ex vivo model of corneal endothelial phacoemulsification injury and rescue therapy with mesenchymal stromal cell secretome. J Cat Refract Surg. 2019; 45 (3): 361-366.

10. Duman R, TokÇevik M, Çevik S, Duman R, İrfan P. Corneal endothelial cell density in healthy Caucasian population. Saudi J Ophthalmol. 2016; 30 (4): 236-239.

11. Foster GJL, Quentin AB, Brandon AD, Devgan U, Richard HS. Sumitra KS, et al. Phacoemulsification 
of the rock-hard dense nuclear cataract: Options and recommendations. J Cat Refract Surg. 2018; 44 (7): 905-916.

12. Kaplowitz K, Yazdanie M, Abazari A. A review of teaching methods and outcomes of resident phacoemulsification. Surv Ophthalmol. 2018; 63 (2): 257-267.

13. Meeks LA, Blomquist PH, Sullivan BR. Outcomes of manual extracapsular versus phacoemulsification cataract extraction by beginner resident surgeons. J Cat Refract Surg. 2013; 39 (11): 1698-1701.

14. Park SJK, Ghee AS, Simon NW, Anthony P. The Effect of Thin, Thick, and Normal Corneas on Goldmann Intraocular Pressure Measurements and Correction Formulae in Individual Eyes. Ophthalmology, 2012; 119 (3): 443-449.

15. Zota IG, Melnic EM, Untesco MI. The Role of Endothelial Cell in the Immune Inflammation Initiation During the Atherosclerosis. Atherosclerosis Supplements, 2008; 9 (1): 224-225.

16. Ludewig $\mathbf{P}$, Winneberger $\mathbf{J}$, Magnus $\mathbf{T}$. The cerebral endothelial cell as a key regulator of inflammatory processes in sterile inflammation. J Neuroimmunol. 2019; 326: 38-44.

17. Zhang S, Wu N, Zhong Y, Weiwei J, Christopher M, Chun J. Optogenetic intervention to the vascular endothelium. Vascular Pharmacol. 2015; 74: 122-129.
18. Cairns R, Graham K, O'Gallagher M, Jackson AJ. Intraocular pressure (IOP) measurements in keratoconic patients: Do variations in IOP respect variations in corneal thickness and corneal curvature? Cont Lens Anterior Eye, 2019; 42 (2): 216-219.

19. Parekh M, Gary PM, Jodhbir S, Ahmad S, Ponzin D, Ferrari S. Effects of corneal preservation conditions on human corneal endothelial cell culture. Exp Eye Res. 2019; 179: 93-101.

20. Blanch RJ, Peter GA, Shah P, Jon BR. Logan AS, Robert AH. Visual Outcomes after Blunt Ocular Trauma. Ophthalmology, 2013; 120 (8): 1588-1591.

21. Aribaba OT, Adenekan OA, Onakoya AO, Samuel AR, Olutola JO, Olatunbosun MK, et al. Central corneal thickness changes following manual small incision cataract surgery. Clin Ophthalmol (Auckland, N.Z.). 2015; 9: 151-155.

22. Deshpande S, Agarwal A, Shah P, Gala Y. Study of central corneal thickness (CCT) before and after smallincision cataract surgery (SICS) and phacoemulsification surgery. Niger J Ophthalmol. 2018; 26 (1): 35-9.

23. Ganekal S, Nagarajappa A. Comparison of morphological and functional endothelial cell changes after cataract surgery: Phacoemulsification versus manual small-incision cataract surgery. Middle East Afr J Ophthalmol. 2014; 21: 56-60. 